\title{
MANAGEMENT OF NEUROGENIC BLADDER DYSFUNCTIONS FOLLOWING ACUTE TRAUMATIC CERVICAL CENTRAL CORD SYNDROME (INCOMPLETE TETRAPLEGIA)
}

\author{
By Inder Perkash, M.D. \\ Spinal Cord Injury Center, Veterans Administration Hospital, \\ Palo Alto and Department of Surgery (Urology), Stanford University, \\ Stanford, California, U.S.A.
}

Abstract. Based on the experience to date with central cord syndrome, most or all of the following conditions should be present before considering transurethral sphincterotomy: (I) minimal neurological recovery within 6 months of injury; (2) four plus spasticity in patients over the age of 50 years; (3) prolonged intermittent catheterisation over 6 months, with persistent residual urine over $300 \mathrm{ml}$; (4) persistent and repeated use of diazepam, dantrolene sodium to control pelvic floor spasticity; (5) demonstrable detrusor-sphincter dyssynergia.

Key words: Bladder dysfunctions management; Incomplete tetraplegia.

\section{Introduction}

CENTRAL cord syndrome is a type of incomplete tetraplegia in which there is sacral sparing following injury and subsequent recovery which starts first in the lower extremities and bladder, and later in the upper extremities (Schneider, 1964). This occurs more frequently in severe hyperextension injuries which cause an anterior posterior squeezing or pinching of the cord. This syndrome may also be associated with cervical arthritis, certain cervical compression fractures, or even flexion fracture dislocation of the cervical spine. Minimal injury may be associated with haematomyelia and oedema of the cord and initially a patient may still present with total tetraplegia.

In a recent I0-year review (Bosch et al., I97I) of 447 patients admitted to Rancho Los Amigos Hospital for traumatic spinal cord injuries, 213 patients were tetraplegics, and among them 42 patients were considered to have had a cervical cord type of lesion. Some degree of neurologic return in the immediate postinjury was recorded in approximately 75 per cent of the patients, with subsequent functional ambulation in about 59 per cent. They also reported 53 per cent recovery in bladder function during the follow-up of such patients.

It is important for a urologist to recognise central cord syndrome since there is a potential for recovery of bladder function. Such patients have to be approached differently than patients who have complete spinal cord transections. Surgical intervention, including transurethral resection of the prostate and transurethral external sphincterotomy, have to be delayed to avoid permanent incontinence in such patients. The present study is a retrospective review of neurogenic bladder dysfunction problems and their management in 25 patients treated during the past 5 years at the VA Hospital, Houston, and the VA Hospital, Palo Alto. Until the present study, exclusive review of neurogenic bladder dysfunctions in central cord syndrome appeared to be non-existent in the literature. 


\section{Materials and Methods}

This study includes all patients with central cord syndrome who were admitted to and discharged from Houston VAH SCI Center between December, I97I and October, 1973 or admitted after November, 1973 to Palo Alto VAH SCI Center. There were 25 male patients, with a mean age of 46 years (range was 19 to 78 years). Neurologic evaluation, muscle testing, and charting were done on admission and were repeated during hospitalisation. Spasticity was graded subjectively as mild, moderate or severe. Diazepam and dantrolene were used for spasticity control.

Patients admitted with Foley indwelling catheters were placed on a programme of intermittent catheterisation (Perkash, 1974). Intermittent catheterisation (IC) was stopped when several urine residuals were $150 / \mathrm{ml}$ or less, and adequate reflex or voluntary voiding was present. The period of IC was considered to have ended when patients went without catheterisation for more than 24 hours, and subsequent catheterisations were for residual check or urine culture rather than for bladder emptying.

Routine urine culture was performed weekly, and additional cultures were obtained frequently. All organisms reported herein as causing significant bacteriuria were present in colony counts greater than $10,000 / \mathrm{ml}$. Positive cultures obtained by midstreams, clean-catch voiding were confirmed by urine cultures obtained by catheterisation or suprapubic aspiration. Urine cultures with organisms present in colony counts less than $10,000 / \mathrm{ml}$ were followed with additional cultures. Significant bacteriuria was treated with an appropriate antimicrobial agent, guided in part by Kirby-Bauer in vitro microbial susceptibility testing. Aminoglycoside therapy was given for 8-10 days, and other antimicrobials were administered for 2-3 weeks. Patients with abnormal bladders were maintained on methenamine mandelate and ascorbic acid when not receiving other antimicrobial agents or on the IC programme.

Excretory urography was performed within the first 3 weeks of admission and was repeated after a year unless normal bladder function developed. Patients not voiding normally or reflexly after 6-8 weeks of IC were studied by cystometrogram with simultaneous electromyogram of the pelvic floor and voiding cystourethrogram. Detrusor activity, the status of the bladder neck and posterior urethra, and detrusor-sphincter dyssynergia (Quesada et al., 1968) were evaluated. Patients demonstrating detrusor-sphincter dyssynergia and marked pelvic floor spasticity were placed on diazepam, dantrolene sodium. Patients presenting with signs and symptoms of autonomic dysreflexia, precipitate micturition and vesicoureteral reflux were also given an anticholinergic drug.

Patients were seen 3-6 weeks after discharge to check residual urine, obtain urine for culture, and to assess neurologic recovery. Subsequent follow-up was at 3-6 month intervals. After November 1973, information about Houston patients was obtained from Houston VAH personnel. Follow-up information on all patients is available up to July 1976.

\section{Results}

Cervical vertebral lesions on 25 patients (Table I) ranged from minimal injury to fracture dislocations. Auto accidents ( 24 per cent), shallow water diving ( 24 per cent), trivial trauma, minor falls, and disc surgery contributed to the rest of the injuries. Post-injury neurosurgical management included anterior fusion in eight patients, removal of a single disc in six, and two discs in two patients; open 
TABLE I

Cervical vertebral injuries for 25 patients

\begin{tabular}{cl}
\hline I. Fracture dislocation $\left(\mathrm{C}_{5}-6=4\right.$ Pts, & \\
$\mathrm{C}_{3}-4=2$ Pts, C6-7 $\left.=\mathrm{I} \mathrm{Pt}\right)$ & 7 cases \\
II. Fracture vertebral bodies $\left(\mathrm{C}_{2}, \mathrm{C}_{4}{ }^{\star} \mathrm{C}_{5}\right)$ & 3 cases \\
III. Herniated disc and cervical spondylosis & 7 cases \\
IV. Compression fracture (C4) & I case \\
V. Tear drop fracture (C7) & I case \\
VI. Narrow cervical canal (minor fall) & I case $+(\mathrm{I})^{\star}$ \\
VII. Subluxation & 3 cases \\
VIII. No demonstrable lesion & 2 cases \\
\hline
\end{tabular}

* He also had fracture $\mathrm{C}_{4}$ as under II.

reduction of a single locked facet and wiring was done in one patient. No surgery was performed in eight patients ( 32 per cent). Post-injury neurologic status on admission to a first hospital, and subsequently to one of the VA Hospital Spinal Cord Injury Centers (VA SCI), is shown in Table II. Six patients were admitted within IO days of injury, I 8 within 2 I to I I 7 days (average 49 days) of injuries, and one patient was admitted 324 days post-injury to VAH. Average hospital stay at VAH was 53 days (43-66 days) in five patients, I83 days (I04-310 days) in I 8 patients. Two patients, still hospitalised (over 6 months), have achieved a balanced bladder.

Within 3 to 6 months post-injury, severe spasticity was noticed in 12 ( 48 per cent) patients, and it persisted during follow-up to an extent that they were nonfunctional ambulators. There was moderate spasticity in four patients, which slightly improved with functional recovery. In three out of nine patients with mild spasticity, about 3 years post-injury, the degree of spasticity has increased and has become a major symptom. Early, severe spasticity was noticed in six patients (out of seven) with disc surgery and spondylosis, in four (out of seven) with fracture dislocations, in one with posterior subluxation, and in one with congenital narrow cervical canal and $\mathrm{T}_{4}$ fracture.

When admitted to one of the VA SCI Centers, 24 patients (96 per cent) had had Foley indwelling catheters placed for a period of 3 to roo days (Table III),

TABLE II

Post-injury neurologic status for 25 patients

\begin{tabular}{lcc}
\hline $\begin{array}{c}\text { Motor activity of } \\
\text { the lower extremity }\end{array}$ & $\begin{array}{c}\text { On admission } \\
\text { (Ist Hosp.) }\end{array}$ & $\begin{array}{c}\star \text { On admission } \\
\text { VAH }\end{array}$ \\
\hline I. Nil to minimal (flicker I muscle) & I3 & I2 \\
2. Fair Minus (gravity eliminated) & 5 & 3 \\
3. Fair plus (against gravity) & 6 & 8 \\
4. Functional & I & 2 \\
\hline
\end{tabular}


and one (C. J.) 324 days post-injury. 
TABLE III

Duration of indwelling catheter following injury

\begin{tabular}{lc}
\hline No. of days & No. of patients \\
A. $3-$ IO & 4 \\
B. II-37 & 7 \\
C. $40-75$ & 5 \\
D. Over 75 days & 5 \\
$\quad$ Total & 24 \\
\hline
\end{tabular}

One admitted with suprapubic cystostomy Io months post-injury.

catheters had been removed from two patients, and in a third immediate removal was followed by full bladder control. One patient was admitted with a suprapubic catheter which had been put in for about Io months.

Significant bacteriuria was detected in 16 out of 22 patients admitted with indwelling catheters. Urine from these patients yielded multiple organisms in seven patients and a single organism in nine patients. The organisms included Pseudomonas, Proteus mirabilis, Proteus rettgeti, Providence, Serratia, Group D Strep., and Candida albicans. The six patients with sterile urine were receiving therapeutic antimicrobials or had had their catheters changed recently. Two of those patients were on continuous bladder irrigations with solution containing neomycin and polymyxin.

J. C. (Table V), who has severe spasticity, non-functional recovery of his legs, and good sensation, was admitted 324 days after injury with a suprapubic indwelling catheter; a soft bladder stone and bilateral vesico-ureteral reflux were present. The suprapubic catheter was removed and replaced with a Foley catheter through the urethra to close suprapubic fistula. After 7 days of antimicrobial therapy, the bladder stone was dissolved by 5 days of continuous renacidin ( 10 per cent) irrigation.

Cystometrographic studies revealed a $50 \mathrm{cc}$ capacity bladder. The patient was given propantheline and converted to reflex voiding within 5 days of IC. Propantheline was continued for 6 weeks. Repeat cystometrographic studies, residual urine check, and voiding cysto-urethrographic studies revealed about I 50 cc capacity bladder, and absence of bilateral vesico-ureteral reflux and post void residue (Fig. Ia and b). A recent intravenous pyelography about a year postdischarge from the hospital showed marked improvement in the pelvicalyceal system (Fig. Ic).

The remaining 2I patients who were admitted with Foley indwelling catheters were placed on intermittent catheterisation (IC), and 17 achieved a balanced bladder (Table IV). Seven required IC for less than I5 days, while eight required 24-60 days (mean 40). In the later group, C. J. (Table IV) achieved satisfactory reflex voiding after 54 days of IC. About 3 weeks later he began to have symptomatic early morning distension with occasional high bladder residuals. Urodynamic studies (Fig. 2a and b) showed detrusor bladder dyssynergia (Fig. 2c), $7 \mathrm{~g}$ of prostatic tissue was removed but sphincterotomy was withheld because 




$\mathrm{CO}_{2}$ Cysto metrogram (90cc/min) \& Sphincterogram $(60 \mathrm{cc} / \mathrm{min})$

FIG. Ia



Fig. Ib

FIG. I

J. C., 66-year-old patient. (a) $\mathrm{CO}_{2}$ (cystometrographic study) shows uninhibited contraction with voiding starting at IOO $\mathrm{cc}$, but he could hold $250 \mathrm{cc}$ of dye (Fig. Ib). Foley no. I 2 catheter withdrawal through bladder neck and posterior urethra (sphincterogram) revealed a fairly flat profile with a sphincter yield pressure of about $40 \mathrm{~cm} \mathrm{H}_{2} \mathrm{O}$. (b) and (c) Voiding cystourethogram revealed bilateral reflux on 24 March 1975 with absent reflux and complete bladder emptying on I May I975. (d) Intravenous pyelography (Io minute films) show marked improvement about 16 months after removal of a suprapubic tube and achieving a catheter free bladder. 



FIG. IC


FIG. Id

further neurological recovery was anticipated (at this point, about 6 months after injury, he had progressed from functionally complete tetraplegic status to an ability to ambulate with a walker). Unfortunately, the patient rejected further IC and hospitalisation and was discharged with a Foley indwelling catheter. He has since developed bladder stones.

Two patients achieved a balanced bladder after a prolonged period of IC. S. M., a 54-year-old male, required 69 days; J. M., a 36-year-old male, required 90 days. J. M. had an areflexic bladder, despite neurologic recovery to the point of having only moderate dysfunction of his hands. He was admitted 3 months after injury, and it was suspected that his bladder has been subjected to a period of overdistension. 


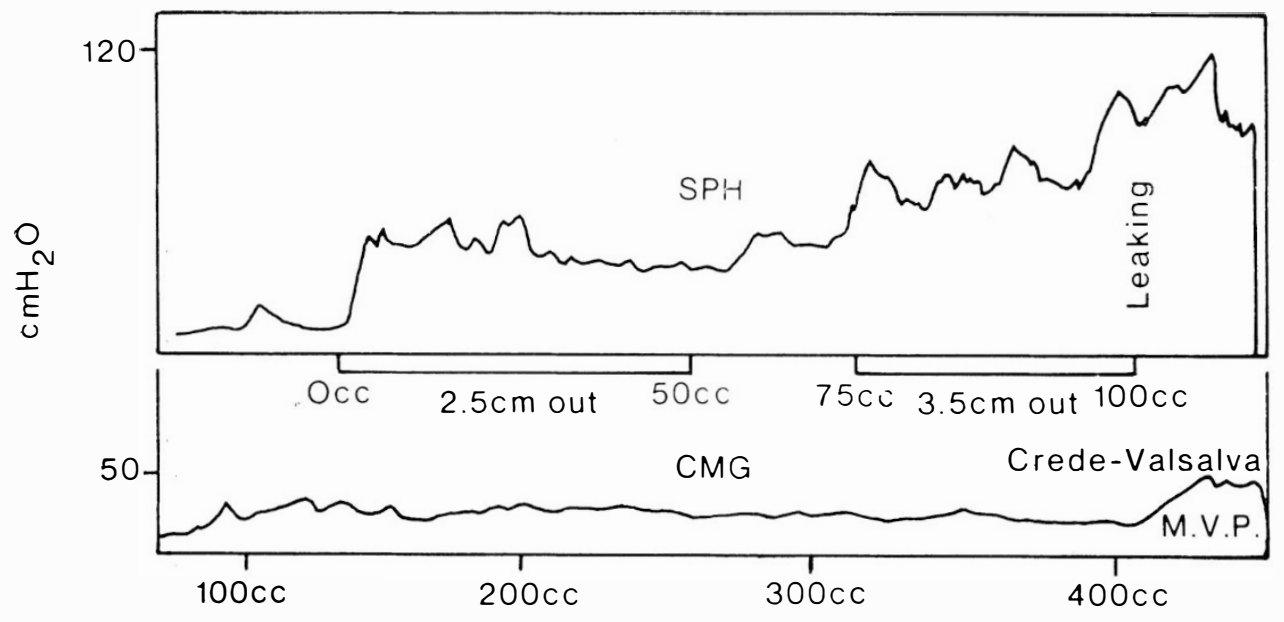

$\mathrm{CO}_{2}$ Cystometrogram $90 \mathrm{cc} / \mathrm{min} \&$ Sphincterogram $(60 \mathrm{cc} / \mathrm{min})$

FIG. 2a


FIG. 2b



FIG. 2c

Fig. 2-Caption at foot of next page. 


\section{TABLE IV}

Duration of intermittent catheterisation for 2I patients

\begin{tabular}{|c|c|c|c|}
\hline $\begin{array}{l}\text { No. of } \\
\text { patients }\end{array}$ & $\begin{array}{l}\text { Period of int. } \\
\text { catheterisation }\end{array}$ & Total no. of caths. & Remarks \\
\hline 7 & $\begin{array}{l}\text { 5-I5 days } \\
\text { (mean Io days) }\end{array}$ & $\begin{array}{l}\text { I3-48 } \\
\text { (mean } 38 \text { caths.) }\end{array}$ & \\
\hline 8 & $\begin{array}{l}24-65 \text { days } \\
\text { (mean } 40 \text { days) }\end{array}$ & $\begin{array}{l}\text { 6I-210 } \\
\quad \text { (mean I22 caths.) }\end{array}$ & $\begin{array}{l}\text { Late failure } \\
\text { rqd. surg. }{ }^{\star}\end{array}$ \\
\hline 6 & $\begin{array}{l}\text { 60-210 days } \\
\text { (mean I25 days) }\end{array}$ & $\begin{array}{l}\text { I } 52-750 \\
\quad \text { (mean } 368 \text { caths.) }\end{array}$ & $\begin{array}{l}3 \text { rqd. surg. }{ }^{\star} \\
\text { I prolonged IC }\end{array}$ \\
\hline
\end{tabular}

\section{TABLE V}

Transurethral surgery in 4 out of 25 male patients $(16 \%)$

\begin{tabular}{|c|c|c|c|c|c|}
\hline $\begin{array}{c}\text { Age } \\
\text { (patient) }\end{array}$ & Lesion & $\begin{array}{l}\text { Period after } \\
\text { injury surgery } \\
\text { performed }\end{array}$ & Indications & $\begin{array}{l}\text { Type of } \\
\text { surgery }\end{array}$ & Results \\
\hline (A. J. S.) & $\begin{array}{l}\mathrm{C}_{3-4} \\
\text { F.D. }\end{array}$ & $\begin{array}{l}\text { I9 months } \\
\text { (wheelchair) }\end{array}$ & $\begin{array}{l}\text { Recov. minimal } \\
\text { Spast. } 4 \text { Plus } \\
\text { Infec. }>60 \% \\
\text { times } \\
\text { Reflux. } \\
\text { D.S.D. }\end{array}$ & $\begin{array}{l}\text { TURP (5G) Mod. } \\
\text { Sphinc. I cm } \\
\text { distal to } \\
\text { veru; cysto- } \\
\text { lithopaxy }\end{array}$ & $\begin{array}{l}\text { Residual }<\text { IOO ml } \\
\text { uninfected } \\
3 \text { months } \\
\text { ( } 9 \text { cultures })\end{array}$ \\
\hline $\begin{array}{r}50 \\
(A . V .)\end{array}$ & $\begin{array}{l}\mathrm{C}_{3} \\
\text { Disc }\end{array}$ & $\begin{array}{l}\text { Io months } \\
\text { (ambulates } \\
\text { normally) }\end{array}$ & $\begin{array}{l}\text { Failed IC } 4 \\
\text { months } \\
\text { Foley } 6 \text { months } \\
\text { Spast. } 2 \text { Plus }\end{array}$ & $\begin{array}{l}\text { TUR bladder } \\
\text { neck } \\
\text { (elsewhere) }\end{array}$ & $\begin{array}{l}\text { Slight incont. } \\
\text { uninfec. } 3 \text { yrs. } \\
\text { (Propantheline } \\
\text { Br.) }\end{array}$ \\
\hline $\begin{array}{l}{ }^{\star} 56 \\
(\text { J. B. }\end{array}$ & $\begin{array}{l}\text { C4-5 \& } \\
\text { C5-6 } \\
\text { Discs }\end{array}$ & $\begin{array}{l}5 \frac{1}{4} \text { months } \\
\text { (wheelchair) }\end{array}$ & $\begin{array}{l}\text { Spast. } 4 \text { Plus } \\
\text { Min. recovery } \\
\text { Difficult IC } \\
\text { Sph. yield pres. } \\
\text { I } 20 \mathrm{~cm} \mathrm{H}_{2} \mathrm{O}\end{array}$ & $\begin{array}{l}\text { TUR Mod. Sph. } \\
\text { I cm distal } \\
\text { to veru }\end{array}$ & $\begin{array}{l}\text { IC } 3 \text { wks post } \\
\text { Sph., and Dantr. } \\
\text { Res. I } 50-200 \mathrm{ml} \\
\text { Uninfected } \\
3 \text { months }\end{array}$ \\
\hline (C. J.) & $\begin{array}{l}C_{3}-4 \& \\
\text { C4-5 } \\
\text { Discs }\end{array}$ & $\begin{array}{l}5 \frac{1}{2} \text { months } \\
\text { (ambulates } \\
\text { with assist. } \\
\text { devices) }\end{array}$ & $\begin{array}{l}\text { Spast. } 4 \text { Plus } \\
\text { D.S.D. } \\
\text { Ureth. pres. } \\
\text { I } 20 \mathrm{~cm} \\
\text { Areflex. blad. }\end{array}$ & TURP only & $\begin{array}{l}\text { D.S.D. } † \text { persist. } \\
\text { Followed on } \\
\text { telephone } \\
\text { Still on Foley } \\
\text { cath. }\end{array}$ \\
\hline
\end{tabular}



FIG. 2

C. J., 54-year-old patient. (a) Cystometrographic study about 4 months post-injury shows 400 cc capacity bladder with some degree of areflexia. Sphincterogram shows marked rise in sphincter yield pressure. (b) Voiding cystourethrogram before and after transurethral resection of the prostate. Patient could only open bladder neck and could not void due to non-relaxation of external urethral sphincter. (c) Pelvic floor electromyographic study shows marked pelvic floor activity on attempted voiding (detrusor sphincter dyssynergia). 



FIG. 3

J. P., I9-year-old patient. Voiding cysto-urethrogram shows marked improvement in the opening of bladder neck and posterior urethra after use of dantrolene sodium, phenoxybenzamine and bethenechol.

Of the remaining four patients who received IC from 60 to $\mathrm{I} 20$ days, one (J. P.) is still receiving IC only twice daily after $\mathrm{I} 80$ days. He has minimal neurologic recovery and severe spasticity. Urodynamic studies, including voiding cysto-urethrogram, showed some voiding improvement after he has been placed on dantrolene, phenoxybenzamine hydrochloride, and bethanechol chloride (Fig. 3).

Three other patients (Tables IV and V) required transurethral surgery. Postoperatively, all achieved satisfactory reflex voiding and the ability to maintain sterile urine. Of the 25 patients in this study, I I were 50 years or older; all four surgical procedures were carried out in this older group (Table V).

Of the 2I patients receiving IC, six developed nine infections while IC was in progress (Table VI). Four of these infections were due to organisms causing significant bacteriuria prior to initiation of IC. Three infections occurred in one patient with vesico-ureteral reflux, and six patients developed infections after withdrawal of IC. All infections were treated and all patients had sterile urine on final discharge.

Type of bladder function achieved at a period about 6 months post-injury is shown in Table VII. No significant changes in bladder status have been noticed in discharged patients during a follow-up of 6 months to $4 \frac{1}{2}$ years. Normal bladder, with no dependence on an external collecting device, was recorded in eight patients. Five patients partly control micturition, but need an external condom to prevent soiling their clothes. All these patients have been on anticholinergic drugs. Ten patients have not developed any control on micturition, even though they had regained minimum sensations of bladder fullness. They were considered as upper motor neuron reflex bladders. 


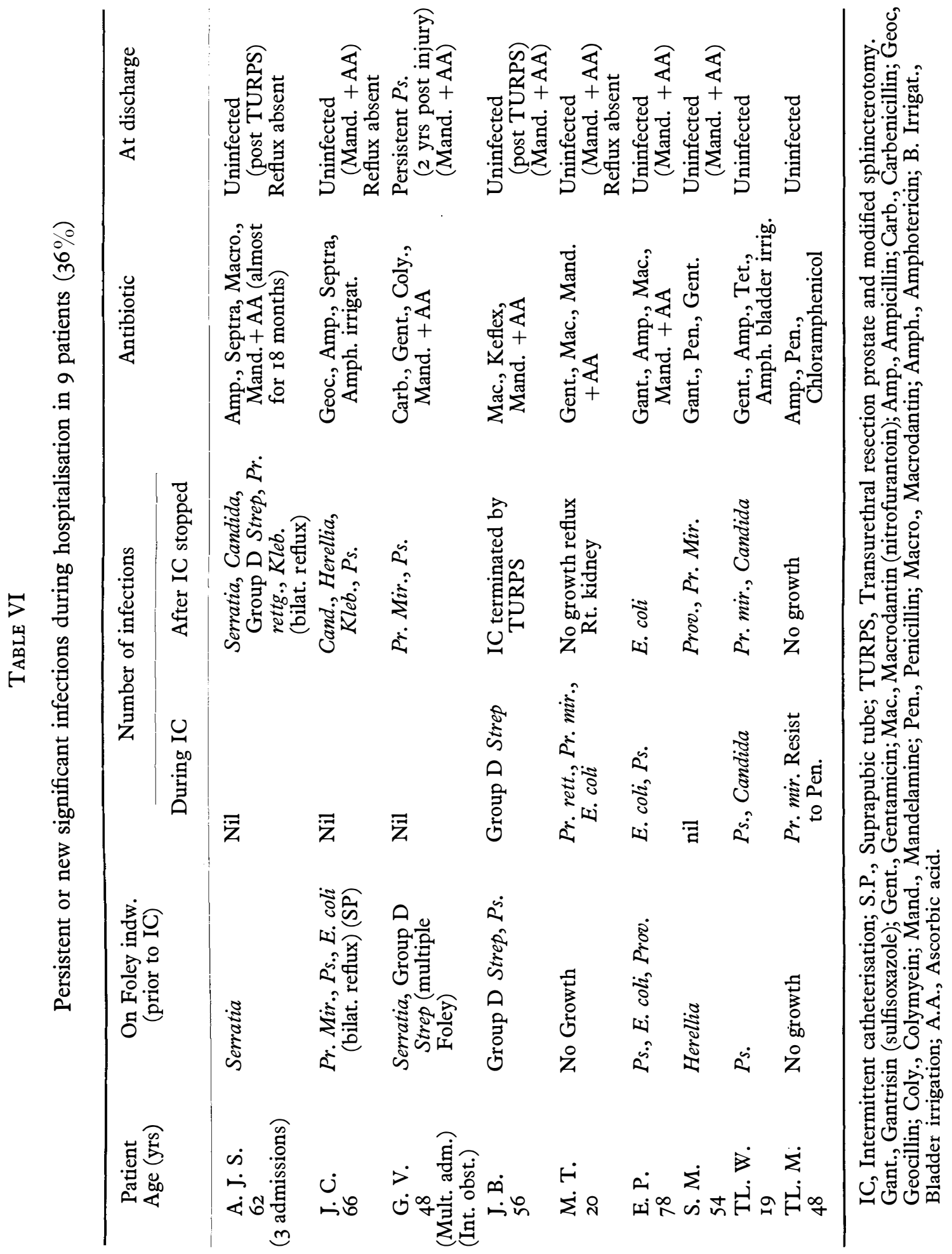




\section{TABLE VII}

Type of bladder 6 months post-injury for 25 patients
A. Normal bladder
8 patients
B. Part normal/upper motor neuron
5
C. Upper motor neuron (external drainage at all times) IO*
D. Prolonged intermittent cath.
E. Foley indwelling catheter

$\star$ Two patients still hospitalised $>6$ months have achieved balanced bladder.

\section{TABLE VIII}

Neurological status 6 months to $4 \frac{1}{2}$ years post-injury for 25 patients

\begin{tabular}{|c|c|c|}
\hline Period after injury & Wheelchair bound & Ambulatory walker \\
\hline $\begin{array}{l}6 \text { months to I year } \\
\text { I year to } 2 \text { years } \\
2 \text { years to } 4 \frac{1}{2} \text { years }\end{array}$ & $\begin{array}{l}3 \\
5 \dagger \\
4 t\end{array}$ & $\begin{array}{l}3 \\
4 \\
6^{\star}\end{array}$ \\
\hline Total & I2 & I3 \\
\hline
\end{tabular}

$\star$ Two patients use crutches; $\dagger$ one patient died (total died $=2$ ).

\section{TABLE IX}

Incidence of significant bacteriuria after discharge from hospital for $2 \mathrm{I}$ patients

\begin{tabular}{lcl}
\hline $\begin{array}{c}\text { Period after } \\
\text { discharge }\end{array}$ & $\begin{array}{c}\text { Total no. } \\
\text { of patients }\end{array}$ & \multicolumn{1}{c}{$\begin{array}{c}\text { Incidence of } \\
\text { infection }\end{array}$} \\
\hline 6-I2 months & 4 & Nil \\
I-2 years & 7 & $\begin{array}{l}2^{\star} \text { Pts. (60\% time) } \\
\text { 2-4 } \frac{1}{2} \text { years }\end{array}$ \\
& I I & $\begin{array}{l}\text { Pts. (only one } \\
\text { infection each) }\end{array}$
\end{tabular}

* One patient uninfected 3 months post-sph., one other 4 Plus spastic minimal recovery.

$\dagger$ Excludes two patients not yet discharged from PAVAH, one on prolonged IC and one patient on Foley catheter. 



FIG. 4a

M.T.



FIG. 4b

FIG. 4

M. T., 20-year-old patient. (a) 8 January 1975, voiding cysto-urethrogram shows vesicoureteral reflux on the (R) side. 28 January 1975 , after use of dantrolene sodium and propanthelene; reflux was not demonstrable. (b) Cystometrographic study on 28 January I 975 shows less sustained activity and marked reduction in sphincter yield pressure compared with studies on 8 January 1975. (c) Follow-up intravenous pyelography on I7 October 1975 shows normal pelvicalyceal system even on the $(\mathrm{R})$ side which had demonstrated reflux on

8 January 1975. Patient has been on dantrolene sodium and on propanthelene. 




FIG. 4C

By the time of this writing, 13 patients became ambulatory (Table VIII). One patient who could ambulate died at age 64,3 years after injury, and one 56year-old wheelchair-bound patient died of pneumonia after pressure sore surgery.

Only four patients using condom drainage developed infections after discharge (Table IX). A. J. S. (Table V) had four separate infections until sphincterotomy was performed, and had none in the following 3 months. Sphincterotomy was recommended for V. G., who has a narrow bladder neck, but he has refused it. Two other infections were asymptomatic Proteus mirabilis infections which did not recur after treatment.

Vesico-ureteral reflux was noticed in one patient (J. C.) immediately following admission, and in two other patients (M. T. and A. J. S.) when IC has been stopped (Table V). They were all infected and had moderate to severe spasticity. Treatment of infection with antimicrobials, use of dantrolene, diazepam and anticholinergic drugs alleviated reflux in all three patients before they were discharged from the hospital. At follow-up they have maintained non-reflux status. Figures $\mathrm{ta}, \mathrm{b}$ and $\mathrm{c}$ show results in one patient.

\section{Discussion}

Recognition of post-traumatic cervical central cord syndrome in the management of neurogenic bladder dysfunction is important, as there is a potential for bladder function recovery. Foerster (1936) placed the sacral segments as the most lateral components of the lateral cortico-spinal tract with the lumbar, thoracic and cervical fibres arranged in that order proceeding from lateral to medial toward the centre of the spinal cord. Therefore, in minimal lesions, associated with central 
haematomyelia and oedema, recovery of function follows a definite pattern. Thus, there is some recovery of bladder function and motor function in the lower extremities, before motor recovery and hand movements in the upper extremities.

In the present group of 25 patients, I 2 ( 48 per cent) had severe cervical cord injuries, seven ( 28 per cent) cervical disc pathology, and six ( 24 per cent) minor injuries. While only two had enough lower extremity muscle power necessary to move against resistance at the time of admission, 13 were ambulating at the time of discharge. Of the 22 not capable of reflex or normal voiding at the time of admission, all of whom required some period of IC, I6 became voiders without surgery. The need for prolonged IC correlated with the early onset of severe spasticity. Thus, early appearance of severe spasticity in 48 per cent of the patients delayed achievement of a balanced bladder on IC; however, use of dantrolene, diazepam and anticholinergic drugs gave us time to appreciate the degree of recovery and thus delay surgical intervention.

It is possible to cause incontinence by an early transurethral surgery, necessitating an external collecting device in these patients. Therefore, in the present series, the overall approach has been conservative in the management of neurogenic bladder dysfunction in such patients. However, bladder status achieved about 6 months post-injury remained unchanged with insignificant further recovery; on the other hand, with increased spasticity, some difficult voiding was noticed during follow-up. Improvement in voiding and lower residuals is worth evaluating following the use of dantrolene and anticholinergic agents. Phenoxybenzamine was used only in two patients with insignificant improvement in voiding in this group of patients. Vesico-ureteral reflux, noticed early in the post-injury period in three patients, could be managed conservatively with the use of dantrolene, anticholinergic agent, and eradication of infection. At the time of discharge from the hospital, the reflux had disappeared and has not reappeared in the three patients.

It is important to separate patients with central cord syndrome from other patients with incomplete tetraplegia. Despite severe neurological dysfunction during the first few weeks, considerable bladder functional recovery can occur, particularly since the bladder fibres are the peripheral ones in the spinal cord. Paradoxically, however, bladder function which will return occurs within the first 6 months, while recovery in the more caphalic segments of the cord continues for I to 2 years. Thus, to avoid unnnecessary surgery and to preserve the potential for continence, urological surgery should be delayed in these patients. Conservative transurethral sphincterotomy and transurethral resection of the prostate is advocated in such patients. Colling's knife incisions need not extend I to $\mathrm{I} \cdot 5 \mathrm{~cm}$ distal to verumontanum (Perkash, 1976).

\section{SUMMARY}

The pattern of neurologic and neuro-urologic recovery in 25 spinal cord injury patients with central cord syndrome is described. Twenty-three patients with indwelling catheters from 3 to Ioo days and one patient with a suprapubic catheter for Io months, were decatheterised. Except for one patient who was admitted with transient quadriparesis, I3 patients ( 52 per cent) had almost total tetraplegia, five patients ( 20 per cent) minimal voluntary movement, and six patients ( 24 per cent) some voluntary activity against gravity in the lower extremities. Bladder rehabilitation was achieved with intermittent catheterisation in 18 patients ( 5 to 96 days), and transurethral surgery in four patients. About 6 
months post-injury, normal bladder was achieved in 32 per cent, partly normal/ reflex in 20 per cent, and reflex bladder in 40 per cent. One patient (failed transurethral resection of the prostate) has a Foley indwelling catheter and one patient is on twice daily intermittent catheterisation for 7 months. Three patients who developed vesico-ureteral reflux were managed successfully. Criteria for transurethral surgery in such patients are discussed.

\section{RÉSUMÉ}

Le mode de convalescence neurologique et urologique de 25 malades atteints de lésions de la moelle épinière, avec syndrome de moelle central, a été décrit. Les cathètres permanents, emplacés de 3 à Ioo jours, en 23 malades, et un cathètre suprapubique de durée de Io mois, ont été éliminés. À l'exception d'un seul malade avec tetraparèse transiente au moment de sa réception, I3 malades $(52 \%)$ souffraient de tetraplégie presque totale, 5 malades $(20 \%)$ étaient capables de mouvements volontaires minimaux, et 6 malades $(24 \%)$ retenaient quelque activité contregravité des pieds. Fonction de la vessie était réhabilitée en I 8 malades traités par cathétrisation intermittante (de 5 à 96 jours) et après opération transuréthral en 4 malades. Le résultat final environ 6 mois après la blessure étaint fonction normale de la vessie en $32 \%$ des malades, normale en partie/réflexe en $20 \%$, et réflex de vessie en $40 \%$. Un des malades (qui n'avait pas réussi en opération transuréthral) est traité par cathètre permanent type Foley, tandis qu'un autre a été traité par des cathétrisations intermittantes, deux fois par jours, pendant 7 mois. Trois malades atteints de reflux vésico-uréthral ont été réhabilités. Les critéria pour intervention surgicale transuréthrale dans ces malades ont été discutés.

\section{ZUSAMMENFASSUNG}

Typische neurologische und urologische Rehabilitierung von Patienten mit Rückenmarksverletzungen wurde beschrieben. In 23 Patienten mit Dauer-Kathetern (von 3-100 Tage) und einem Patient mit Katheter über dem os pubis (IO Monate), konnten die Katheter entfernt werden. Mit Ausnahme eines Patienten, der bei der Aufnahme vorübergehende Tetraparesis zeigte, hatten I3 Patienten $(52 \%)$ fast vollständige Tetraplegie, 5 Patienten $(20 \%)$ hatten minimale Bewegung, und 6 Patienten $(24 \%)$ etwas Bewegung der Füsse gegen die Schwerkraft. Blasen-Funktion wurde in is Patienten wiederhergestellt mit intermittierender Katheterisierung (5-96 Tage) und trans-urethraler Operation (externe Sphinkterotomie) in 4 Patienten. Ungefähr 6 Monate nach der Verletzung wurden die folgenden Resultate verzeichnet: Normale Blasen Funktion in $32 \%$ der Patienten, partiell normale/Reflex Funktion in $20 \%$, und Reflex Funktion in $40 \%$. Ein Patient, in dem die externe Sphinkterotomie nicht erfolgreich war, wurde mit einem Foley Dauer-Katheter behandelt, und ein anderer Patient wurde zwei mal täglich für 7 Monate Katheterisiert. Drei Patienten mit vesiko-urethralem Reflux wurden erfolgreich behandelt. Die Indikation für externe Sphinkterotomie in diesen Patienten wurde besprochen.

\section{REFERENCES}

Bosch, A., Stauffer, S. \& Nickel, V. L. (I97I). Incomplete traumatic quadriplegia. F.A.M.A. 216, 473 .

FoERSTER, O. (I936). Symptomatologic der Erkrankungen des Rückenmarks und seiner Wurzeln. Bumke u. Foersters Handb. Neurol. 5, 83.

PERKASH, I. (I974). Intermittent catheterization: the urologist's point of view. Fournal of Urology, III, 356.

PERKash, I. (I976). Modified approach to sphincterotomy in spinal cord injury patients: indications, techniques and results in 32 patients. Paraplegia, 13, 247.

QuesadA, E. M., SCOT, F. B. \& CARDus, D. (I968). Functional classification of neurogenic bladder dysfunction. Arch. Phys. Med. 49, 693.

Schneider, R. C., Cherry, G. \& Pentek, H. (I954). The syndrome of acute central cervical spinal cord injury. $\mathcal{F}$. Neurosurgery, II, 546.

Acknowledgements. Thanks are due to Dr Fred Lewis, Houston, VA Hospital, Spinal Cord Injury Service, and my colleague, Frank S. Rhame, M.D., for help preparing this manuscript. 